\begin{tabular}{|l|l|}
\hline JITAS & $\begin{array}{l}\text { JAGROS Journal of Agrotechnonogy and Science } \\
\text { Jurnal Agroteknologi dan sains } \\
\text { Fakultas Pertanian, Universitas Garut } \\
\text { P ISSN : 2775-0485, E ISSN : 2548-7752 }\end{array}$ \\
\hline
\end{tabular}

\title{
Pengaruh Pemberian Biochar dan Pupuk Hayati Terhadap Pertumbuhan dan Hasil Pakcoy (Brassica rapa L.)
}

\section{The Effect of Biochar and Biofertilizer on Growth and Yield of Pakcoy (Brassica rapa L.)}

\author{
Irpan Ansori, Hanny Hidayati Nafi'ah*, dan Dadi Nurdiana \\ Fakultas Pertanian Universitas Garut \\ *hanny.hidayati@uniga.ac.id
}

\begin{abstract}
Abstrak
Pakcoy (Brassica rapa L.) merupakan salah satu jenis sayuran yang digemari oleh masyarakat Indonesia. Terdapat banyak jenis makanan di Indonesia banyak yang menggunakan daun pakcoy sebagai bahan makanan utama maupun sebagai pelengkap. Banyaknya kebutuhan pakcoy mengakibatkan harus ditingkatkan produksinya. Penelitian ini bertujuan untuk mengetahui dosis biochar dan pupuk hayati yang dapat meningkatkan pertumbuhan dan hasil tanaman pakcoy. Percobaan dilaksanakan di Kampung Baruparos Desa Sirnajaya, Kecamatan Tarogong Kaler, Kabupaten Garut, Jawa Barat. Penelitian dilaksanakan pada bulan Mei sampai dengan Juni 2021. Metode penelitian yang digunakan adalah metode eksperimental dengan menggunakan Rancangan Acak Kelompok (RAK) pola faktorial 4 x 4 yang diulang sebanyak dua kali. Faktor pertama dosis biochar (B) yang terdiri dari 4 taraf perlakuan, yaitu: $b_{1}=0$ ton/ha, $b_{2}=3$ ton $/$ ha, $b_{3}=6$ ton/ha, dan $b_{4}=9$ ton/ha. Faktor kedua yaitu pemberian konsentrasi pupuk hayati $(\mathrm{H})$ terdiri dari 4 taraf, yaitu: $\mathrm{h}_{0}=0 \mathrm{ml} / \mathrm{l}$ air, $\mathrm{h}_{1}=5 \mathrm{ml} / \mathrm{l}$ air, $\mathrm{h}_{2}=10 \mathrm{ml} / \mathrm{l}$ air, dan $\mathrm{h}_{3}=15 \mathrm{ml} / \mathrm{l}$ air. Hasil penelitian menunjukkan tidak terdapat interaksi antara biochar dan pupuk hayati terhadap pertumbuhan dan hasil tanaman pakcoy. Secara mandiri, dosis biochar 6 dan 9 ton/ha dan konsentrasi pupuk hayati $15 \mathrm{ml} / \mathrm{l}$ memberikan pengaruh yang berbeda nyata terhadap pertumbuhan dan hasil tanaman pakcoy.
\end{abstract}

Kata kunci: biochar, pakcoy, dan pupuk hayati.

\section{Abstract}

Pakcoy (Brassica rapa L.) is one of the most popular types of vegetable in Indonesia. There are many types of food in Indonesia, many of which use pakcoy leaves as the main food ingredient and as a complement. The demand of pakcoy has resulted in the need for increased production. This study aimed to find out the dose of biochar and biofertilizers that can increase the growth and yield of pakcoy plants. The experiment was conducted in Kampung Baruparos Sirnajaya Village, Tarogong Kaler District, Garut Regency, West Java. The study was conducted from May to June 2021. The research method used is an experimental method using a Randomized Group Design $4 \times 4$ factorial pattern that is repeated twice. The first factor of biochar $(B)$ dose consisting of 4 treatment standards, namely: $b 1=0$ tons $/$ ha, $b 2=3$ tons $/ h a, b 3=6$ tons $/ h a$, and $b 4=9$ tons $/$ ha . The 
second factor is the concentration of biological fertilizer $(H)$ consists of 4 levels, namely: $h 0=0 \mathrm{ml} / \mathrm{l}$ water, $h 1=5 \mathrm{ml} / \mathrm{l}$ water, $h 2=10 \mathrm{ml} / \mathrm{l}$ of water, and $\mathrm{h} 3=15 \mathrm{ml} / \mathrm{l}$ of water. The results showed no interaction between biochar and biofertilizers to the growth and yield of pakcoy plants. Independently, biochar doses of 6 and 9 tons/ha and a concentration of $15 \mathrm{ml} / \mathrm{l}$ of biological fertilizers have a noticeable distinct influence on the growth and yield of pakcoy plants.

Keywords: biochar, biofertilizer, and pakcoy.

\section{PENDAHULUAN}

Pakcoy merupakan salah satu varietas dari tanaman sawi yang dimanfaatkan daunnya sebagai sayuran. Terdapat banyak jenis makanan di Indonesia banyak yang menggunakan daun pakcoy sebagai bahan makanan utama maupun sebagai pelengkap. Pakcoy banyak mengandung protein, lemak, karbohidrat, $\mathrm{Ca}, \mathrm{P}, \mathrm{Fe}$, vitamin $\mathrm{A}, \mathrm{B}, \mathrm{C}, \mathrm{E}$ dan $\mathrm{K}$ yang sangat baik untuk kesehatan (Haryanto dkk., 2007; Prasetyo, 2010). Kandungan gizi dalam sawi pakcoy sangat baik terutama untuk ibu hamil karena dapat menghindarkan dari anemia (Pracaya dan Kartika, 2016). Kurniadi (1996) menyatakan pakcoy selain sebagai sayuran juga dapat bermanfaat bagi kesehatan manusia, terutama yang mengkonsumsinya secara kontinyu. Karena banyak manfaat yang dimiliki pakcoy menyebkan jenis sayuran ini banyak digemari masyarakat.

Pakcoy lebih banyak digemari dibandingkan sawi lainnya. Batang dan daunnya yang lebih lebar dari sawi hijau biasa, membuat sawi jenis ini lebih sering digunakan masyarakat dalam berbagai menu masakan (Yuliani, 2015). Hal ini memberikan prospek bisnis yang cukup cerah bagi para petani sawi pakcoy. Berdasarkan kebutuhan dan prospek bisnis ini maka perlu dilakukan upaya untuk meningkatkan produksi pakcoy.

Salah satu upaya yang dapat dilakukan untuk meningkatkan produksi adalah pemberian pembenah tanah. Pemberian bahan pembenah tanah ini dapat mempengaruhi agregat tanah yang akan mempengaruhi pertumbuhan dan hasil tanaman (Septiana dkk., 2021). Bahan pembenah tanah yang digunakan dapat berupa biochar arang sekam. Biochar adalah bahan padat kaya karbon hasil konversi dari limbah organik pertanian melalui pembakaran dengan suplai oksigen terbatas (Winata dan Zainul, 2020). Aplikasi biochar ke lahan pertanian yang kering maupun basah dapat meningkatkan kemampuan tanah menyimpan air dan unsur hara (Pakpahan dkk., 2020), memperbaiki kegemburan tanah (Surianti dkk., 2021), dan menciptakan habitat yang baik untuk mikroba rizosfer (Sasmita dkk., 2021). Biochar tidak mampu menyediakan unsur hara secara langsung 
(Juhari dkk, 2021). Maka dari itu, aplikasi biochar perlu dilengkapi dengan pemberian pupuk lain, salah satunya pupuk hayati.

Pemberian pupuk hayati dapat membantu meningkatkan pertumbuhan tanaman. Hal ini karena pupuk hayati mengandung Plant Growth Promoting Rhizobacteria (PGPR) hidup (Setiawati dkk, 2014). Hasil penelitian lain mengungkapkan bahwa pemberian pupuk hayati campuran dari Pseudomonas sp., Bacillus sp., dan Streptomyces sp. dengan 50\% pupuk NPK rekomendasi selain dapat meningkatkan pertumbuhan vegetatif tanaman, juga meningkatkan sifat biokimia tanah dan hasil Citrullus lanatus dibandingkan dengan perlakuan lainnya (Antonius dan Agustiyani, 2011). Pupuk hayati dapat meningkatkan hasil ubi kayu (Nafi'ah dkk., 2019) dan ubi jalar (Nafi'ah dkk., 2021). Pupuk hayati dapat diberikan ke dalam tanah bersama bahan organik lain untuk meningkatkan produksi tanaman, salah satunya dengan biochar.

Biochar dan pupuk hayati dilaporkan dapat berinteraksi dalam meningkatkan pertumbuhan dan hasil tanaman. Dilaporkan Alianti dkk (2016) pemberian biochar 6 t.ha ${ }^{-}$ ${ }^{1}$ dan pupuk hayati 2 t.ha $^{-1}$ dapat berinteraksi dan merupakan perlakuan terbaik dalam meningkatkan bobot panen tomat. Pemberian biochar dan pupuk hayati diharapkan dapat meningkatkan pertumbuhan dan hasil pakcoy.

Tujuan peneilitian ini adalah untuk mengetahui dosis biochar dan konsentrasi pupuk hayati yang dapat memberikan pengaruh terbaik dalam meningkatkan pertumbuhan dan hasil tanaman pakcoy.

\section{BAHAN DAN METODE PENELITIAN}

Percobaan dilaksanakan di Kampung Baruparos Desa Sirnajaya, Kecamatan Tarogong Kaler, Kabupaten Garut, Jawa Barat. Waktu penelitian dilaksanakan pada bulan Mei sampai dengan Juni 2021. Rata-rata temperatur harian $28^{\circ} \mathrm{C}$.

Bahan percobaan yang digunakan adalah benih tanaman pakcoy varietas Green, biochar arang sekam, dan pupuk hayati (Bion Up, PT. Kujang). Alat yang digunakan terdiri dari cangkul, tray semai, timbangan, kawat, label/papan nama, blangko pengamatan, kamera, ember, timbangan digital dan plastik.

Penelitian dilakukan dengan menggunakan metode eksperimen dengan Rancangan Acak Kelompok (RAK) pola faktorial $4 \mathrm{x} 4$ yang terdiri dari 2 perlakuan dan diulang dua 
kali, sehingga didapatkan 32 plot percobaan. Setiap plot terdiri dari 18 tanaman, sehingga jumlah tanaman keseluruhan adalah sebanyak 576 tanaman.

Faktor perlakuan pertama adalah dosis biochar (B) yang terdiri dari 4 taraf perlakuan, yaitu: $b_{1}\left(0\right.$ ton/ha), $b_{2}$ (3 ton/ha), $b_{3}$ (6 ton/ha), dan $b_{4}$ (9 ton/ha). Faktor kedua yaitu pemberian konsentrasi pupuk hayati $(\mathrm{H})$ terdiri dari 4 taraf, yaitu: $\mathrm{h}_{0}(0 \mathrm{ml} / \mathrm{l}$ air $), \mathrm{h}_{1}(5$ $\mathrm{ml} / \mathrm{l}$ air $), \mathrm{h}_{2}(10 \mathrm{ml} / \mathrm{l}$ air $)$, dan $\mathrm{h}_{3}(15 \mathrm{ml} / \mathrm{l}$ air $)$.

Data dianalisis menggunakan Analisis Ragam RAK faktorial taraf 5\%. Jika F hitung lebih besar dari $\mathrm{F}$ tabel maka dilakukan uji lanjut menggunakan Uji Jarak Berganda Duncan. Pengamatan yang dilakukan yaitu: Tinggi Tanaman (cm), Jumlah Daun (helai), Luas Daun $\left(\mathrm{cm}^{2}\right)$, Bobot Segar per Tanaman $(\mathrm{g})$, Bobot Kering per Tanaman $(\mathrm{g})$, danBobot Tanaman per Plot (g).

Benih pakcoy disemaikan dengan media semai tanah dan pupuk kandang dengan perbandingan 1:1. Persemaian dilakukan pada tray semai. Tiap lubang tray semai ditanami 1-2 benih pakcoy. Umur 14 hari setelah semai (HSS) benih pakcoy sudah bisa ditanam di lahan.

Aplikasi Biochar dilakukan dengan cara dicampur dengan pupuk hayati. Pencampuran dilakukan disesuaian dengan masing-masing perlakuan yang ditentukan. Aplikasi pupuk hayati dilakukan sebanyak tiga kali, yaitu pada saat sebelum tanam bersamaan dengan pemberian biochar dengan cara pupuk hayati sesuai dosis perlakuan masing-masing, dicampur dengan biochar sampai homogen kemudian ditutup tanah dan dibiarkan selama 1 minggu. Aplikasi susulan dilakukan pada saat tanaman berumur 7 dan 14 HST, dengan cara diberikan langsung pada tanah di sekitar perakaran.

Lahan yang digunakan sebagai tempat penelitian dibersihkan dari sisa-sisa tanaman dan gulma, kemudian dibuat bedengan dengan ukuran per plot $60 \mathrm{~cm}$ x $120 \mathrm{~cm}$. Setelah selesai dibuat ukuran per plot, bedengan diberikan campuran biochar dan pupuk hayati dengan dosis sesuai dengan masing-masing perlakuan. Setelah bibit pakcoy berumur 14 HSS, bibit siap ditanam. Bibit pakcoy ditanam di bedengan dengan jarak tanam $10 \times 15$ cm. Setiap plot ditanami dengan 18 tanaman.

Penyiangan dilakukan satu kali, yaitu pada umur tanaman 1 MST. Tujuan penyiangan adalah membersihkan tumbuhan liar yang akan menghambat pertumbuhan tanaman. Penyulaman adalah kegiatan mengganti tanaman yang mati, tidak tumbuh, atau tumbuh tidak normal dengan tanaman baru yang sehat. Kegiatan ini dilakukan pada umur tanaman 
7 HST. Penyiraman dilakukan setiap hari bila tidak ada hujan. Penyiraman dilakukan pagi atau sore hari dan tergantung pada kebutuhan tanaman terutama bila keadaan tanah cepat kering dan musim kemarau, penyiraman dilakukan sesuai kebutuhan tanaman agar pemberian air lebih efektif. Pengendalian hama dan penyakit dilakukan dengan sistem PHT (Pengendalian Hama Terpadu), yaitu pengendalian secara bertahap dari mulai pengendalian secara biologis, mekanis, kimiawi. Pemanenan pakcoy dilakukan pada umur 40 HST. Pemanenan dilakukan dengan cara mengambil seluruh bagian tanaman secara utuh.

\section{HASIL DAN PEMBAHASAN}

\section{Tinggi Tanaman $(\mathbf{c m})$}

Berdasarkan hasil analisis statistik dengan taraf 5\%, menunjukkan bahwa tidak terjadi interaksi antara dosis biochar dan konsentrasi pupuk hayati, namun secara mandiri dosis biochar dan konsentrasi pupuk hayati memberikan pengaruh yang berbeda nyata terhadap rata-rata tinggi tanaman pada semua pengamatan. Nilai rata-rata tinggi tanaman dapat dilihat pada Tabel 1 .

Tabel 1. Rata-rata Tinggi Tanaman $(\mathrm{cm})$

\begin{tabular}{lccc}
\hline Perlakuan & 10 HST $(\mathrm{cm})$ & 20 HST $(\mathrm{cm})$ & 30 HST $(\mathrm{cm})$ \\
\hline Dosis Biochar (B) & $10,33 \mathrm{a}$ & $15,46 \mathrm{a}$ & $20,50 \mathrm{a}$ \\
$\mathrm{b}_{1}(0$ ton/ha) & $10,61 \mathrm{a}$ & $16,09 \mathrm{ab}$ & $20,35 \mathrm{ab}$ \\
$\mathrm{b}_{2}(3 \mathrm{ton} / \mathrm{ha})$ & $11,45 \mathrm{~b}$ & $16,95 \mathrm{bc}$ & $21,68 \mathrm{bc}$ \\
$\mathrm{b}_{3}(6 \mathrm{ton} / \mathrm{ha})$ & $11,93 \mathrm{~b}$ & $17,58 \mathrm{c}$ & $22,83 \mathrm{c}$ \\
$\mathrm{b}_{4}(9 \mathrm{ton} / \mathrm{ha})$ & $10,40 \mathrm{a}$ & $15,68 \mathrm{a}$ & $20,75 \mathrm{a}$ \\
\hline Konsentrasi Pupuk Hayati $(\mathrm{H})$ & $10,84 \mathrm{a}$ & $16,03 \mathrm{a}$ & $20,93 \mathrm{a}$ \\
$\mathrm{h}_{0}(0 \mathrm{ml} / \mathrm{l}$ air $)$ & $11,08 \mathrm{a}$ & $16,41 \mathrm{a}$ & $21,01 \mathrm{a}$ \\
$\mathrm{h}_{1}(5 \mathrm{ml} / \mathrm{l}$ air) & $12,00 \mathrm{~b}$ & $17,96 \mathrm{~b}$ & $22,66 \mathrm{~b}$ \\
$\mathrm{~h}_{2}(10 \mathrm{ml} / \mathrm{l}$ air $)$ & Angka rata-rata yang ditandai dengan huruf & yang sama \\
$\mathrm{h}_{3}(15 \mathrm{ml} / \mathrm{l}$ air) & menunjukkan tidak berbeda nyata menurut Uji Lanjut Duncan \\
\hline Keterangan: & pada taraf 5\%. &
\end{tabular}

Taraf faktor $b_{3}$ dan $b_{4}$ menunjukkan tinggi tanaman yang semakin meningkat pada setiap pengamatan dan berbeda nyata dengan taraf faktor $b_{1}$ dan $b_{2}$. Diduga pemberian biochar pada taraf $b_{3}$ dan $b_{4}$ merupakan perlakuan yang cukup tepat dalam menunjang pertumbuhan akar dan penyimpanan unsur hara untuk pertumbuhan tanaman. Akibat dari lebih baiknya kondisi tanah menjadikan tinggi tanaman pada perlakuan $\mathrm{b}_{3}$ dan $\mathrm{b}_{4}$ berbeda 
nyata. Menurut Ketut dkk., (2017), aplikasi biochar secara nyata berpotensi dalam meningkatkan beberapa sifat kimia tanah seperti $\mathrm{pH}$ tanah, KTK, dan beberapa senyawa seperti C-organik, N-total, serta dapat mereduksi aktivitas senyawa Fe dan Al yang berdampak terhadap peningkatan $\mathrm{P}$ tersedia. Hal ini sesuai dengan penelitian Rondon dkk., (2007) yang menyatakan bahwa penggunaan biochar dapat meningkatkan fiksasi nitrogen, memperbaiki pertumbuhan dan meningkatkan hasil tanaman. Dosis biochar 6 ton/ha sudah cukup untuk meningkatkan tinggi tanaman.

Pemberian pupuk hayati dengan taraf perlakuan $\mathrm{h}_{0}, \mathrm{~h}_{1}, \mathrm{~h}_{2}$ berbeda nyata dengan taraf perlakuan $h_{3}$ (Tabel 1). Pemberian bakteri menguntungkan dari pupuk diduga mampu meningkatkan ketersediaan unsur hara dalam tanah, dalam hal ini peningkatan pertumbuhan tanaman dicapai pada tingkat pemberian $\mathrm{h}_{3}$. Menurut Kumar dkk., (2017), pupuk hayati (Biofertilizer) mengandung mikroorganisme yang dapat memacu pertumbuhan tanaman, menambat nitrogen, melarutkan fosfat dan menghambat pertumbuhan penyakit tanaman. Diduga aktivitas mikroorganisme menguntungkan inilah yang dalam taraf $\mathrm{h}_{3}(15 \mathrm{ml} / \mathrm{l}$ air ) mampu memberikan tambahan nutrisi dan meningkatkan tinggi tanaman.

\section{Jumlah Daun (helai)}

Berdasarkan hasil analisis statistik dengan taraf 5\%, menunjukkan bahwa tidak terjadi interaksi antara dosis biochar dan konsentrasi pupuk hayati, namun secara mandiri dosis biochar dan konsentrasi pupuk mampu memberikan pengaruh yang berbeda nyata terhadap rata-rata jumlah daun pada semua umur pengamatan. Nilai rata-rata jumlah daun dapat dilihat pada Tabel 2 .

Tabel 2. Rata-rata Jumlah Daun (Helai)

\begin{tabular}{lccc}
\hline Perlakuan & $\begin{array}{c}\text { 10 HST } \\
\text { (helai) }\end{array}$ & $\begin{array}{c}\text { 20 HST } \\
\text { (helai) }\end{array}$ & $\begin{array}{c}30 \mathrm{HST} \\
\text { (helai) }\end{array}$ \\
\hline $\begin{array}{l}\text { Dosis Biochar (B) } \\
\mathrm{b}_{1}(0 \text { ton/ha) }\end{array}$ & $5,95 \mathrm{a}$ & $7,73 \mathrm{a}$ & $11,03 \mathrm{a}$ \\
$\mathrm{b}_{2}(3 \mathrm{ton} / \mathrm{ha})$ & $6,03 \mathrm{a}$ & $8,08 \mathrm{ab}$ & $11,35 \mathrm{a}$ \\
$\mathrm{b}_{3}(6 \mathrm{ton} / \mathrm{ha})$ & $6,74 \mathrm{~b}$ & $8,39 \mathrm{bc}$ & $12,63 \mathrm{~b}$ \\
$\mathrm{~b}_{4}(9$ ton/ha) & $6,53 \mathrm{~b}$ & $8,75 \mathrm{c}$ & $12,58 \mathrm{~b}$ \\
\hline Konsentrasi Pupuk Hayati $(\mathrm{H})$ & & & \\
$\mathrm{h}_{0}(0 \mathrm{ml} / \mathrm{l}$ air) & $6,03 \mathrm{a}$ & $7,94 \mathrm{a}$ & $11,38 \mathrm{a}$ \\
$\mathrm{h}_{1}(5 \mathrm{ml} / \mathrm{l}$ air) & $6,08 \mathrm{a}$ & $8,00 \mathrm{a}$ & $11,78 \mathrm{ab}$ \\
$\mathrm{h}_{2}(10 \mathrm{ml} / \mathrm{l}$ air $)$ & $6,39 \mathrm{ab}$ & $8,24 \mathrm{a}$ & $12,03 \mathrm{ab}$ \\
$\mathrm{h}_{3}(15 \mathrm{ml} / \mathrm{l}$ air $)$ & $6,75 \mathrm{~b}$ & $8,76 \mathrm{~b}$ & $12,40 \mathrm{~b}$ \\
\hline
\end{tabular}




\begin{tabular}{ll}
\hline Keterangan: & $\begin{array}{l}\text { Angka rata-rata yang ditandai dengan huruf yang sama } \\
\text { menunjukkan tidak berbeda nyata menurut Uji Lanjut Duncan }\end{array}$ \\
& pada taraf 5\%.
\end{tabular}

Pemberian dosis biochar pada taraf $b_{3}$ dan $b_{4}$ diduga mampu meningkatkan hasil rata-rata jumlah daun pada pertanaman pakcoy (Tabel 2). Pemberian biochar mampu menjaga unsur hara dalam tanah agar tidak mudah hanyut terbawa air. Hale dkk., (2013), membuktikan bahwa biochar mampu meretensi $\mathrm{N}$ dan $\mathrm{P}$ sehingga tidak mudah hanyut terbawa air dan akan lebih tersedia bagi tanaman. Perlakuan biochar sekam padi dapat meningkatkan serapan tanaman terhadap pupuk NPK. Serapan tanaman yang semakin besar maka hasil yang diperoleh akan optimal (Zulfita dkk., 2019). Melambatnya pengaruh pencucian unsur hara menjadikan lebih optimalnya serapan unsur hara bagi tanaman.

Hasil analisis ragam pupuk hayati menunjukkan berbeda nyata antara taraf perlakuan $h_{0}, h_{1}, h_{2}$ dibanding taraf perlakuan $h_{3}$. Diduga taraf perlakuan $h_{3}$ merupakan taraf perlakuan yang terbaik dibanding taraf perlakuan lainnya pada saat percobaan. Hasil dari bakteri baik yang menghasilkan nutrisi bagi tanaman digunakan oleh tanaman untuk meningkatkan pertumbuhan vegetatif. Menurut Gardner dkk., (1991) menyatakan bahwa sepanjang masa pertumbuhan vegetatif, akar, daun dan batang merupakan bagian-bagian dari tanaman yang kompetitif dalam pemanfaatan hasil asimilasi. Anggraheni, dkk, (2017) pada fase vegetatif proporsi energi yang dibutuhkan untuk proses pertumbuhan cabang dan daun tanaman lebih besar dari pada energi yang dibutuhkan untuk proses pertumbuhan bagian tanaman lainnya. Hasil Penelitian lain mengungkapkan bahwa pemberian pupuk hayati campuran dari Pseudomonas sp., Bacillus sp., dan Streptomyces sp. dengan 50\% pupuk NPK rekomendasi selain dapat meningkatkan pertumbuhan vegetatif tanaman, juga meningkatkan sifat biokimia tanah dan hasil Citrullus lanatus dibandingkan dengan perlakuan lainnya (Antonius dan Agustiyani 2011). Diduga pemberian pupuk hayati taraf $h_{3}$ mampu memberikan tambahan unsur hara yang cukup dalam menunjang pertumbuhan vegetatif pada pertanaman pakcoy dilahan percobaan.

\section{Luas Daun $\left(\mathrm{cm}^{2}\right)$}

Berdasarkan hasil analisis statistik dengan taraf 5\%, menunjukkan bahwa tidak terjadi interaksi antara dosis biochar dan konsentrasi pupuk hayati, namun secara mandiri 
dosis biochar dan konsentrasi pupuk mampu memberikan pengaruh yang berbeda nyata terhadap rata-rata luas daun. Tabel 3.

Tabel 3. Rata-rata Luas Daun $\left(\mathrm{cm}^{2}\right)$

\begin{tabular}{lc}
\hline Perlakuan & Luas Daun $\left(\mathrm{cm}^{2}\right)$ \\
\hline Dosis Biochar $(\mathrm{B})$ & \\
$\mathrm{b}_{1}(0$ ton/ha) & $613,69 \mathrm{a}$ \\
$\mathrm{b}_{2}(3$ ton/ha) & $680,79 \mathrm{a}$ \\
$\mathrm{b}_{3}(6$ ton/ha) & $799,55 \mathrm{~b}$ \\
$\mathrm{~b}_{4}(9$ ton/ha) & $812,82 \mathrm{~b}$ \\
\hline
\end{tabular}

Konsentrasi Pupuk Hayati $(\mathrm{H})$

$\begin{array}{ll}\mathrm{h}_{0}(0 \mathrm{ml} / \mathrm{l} \text { air }) & 681,88 \mathrm{a} \\ \mathrm{h}_{1}(5 \mathrm{ml} / \mathrm{l} \text { air }) & 663,82 \mathrm{a} \\ \mathrm{h}_{2}(10 \mathrm{ml} / \mathrm{l} \text { air }) & 727,06 \mathrm{a} \\ \mathrm{h}_{3}(15 \mathrm{ml} / \mathrm{l} \text { air }) & 834,10 \mathrm{~b}\end{array}$

Keterangan: Angka rata-rata yang ditandai dengan huruf yang sama menunjukkan tidak berbeda nyata menurut Uji Lanjut Duncan pada taraf $5 \%$.

Hasil analisis ragam biochar menunjukkan taraf perlakuan $b_{3}$ dan $b_{4}$ dapat meningkatkan luas daun pakcoy (Tabel 3). Diduga pemberian biochar mampu menjaga unsur hara tidak tercuci oleh air sehingga mampu dimanfaatkan lebih baik oleh tanaman. Sesuai dengan pendapat Lehmann dan Joseph (2009), perlakuan biochar sekam padi mampu meningkatkan kapasitas menahan air, KTK, maupun menyediakan unsur hara dalam memperbaiki serapan hara oleh tanaman sehingga menyebabkan kesuburan tanah semakin tinggi. Peningkatan ketersediaan unsur hara menjadikan lebih baiknya pemanfaatan dalam membentuk jaringan pada tanaman terutama daun pada fase vegetatif. Unsur hara yang lebih tersedia juga mampu meningkatkan proses fotosintesis didaun karena lebih luasnya jaringan daun yang berhasil dibentuk.

Hasil analisis ragam pupuk hayati menunjukkan berbeda nyata antara taraf perlakuan $h_{0}, h_{1}, h_{2}$ dibanding taraf perlakuan $h_{3}$ (Tabel 3). Diduga taraf perlakuan $h_{3}$ merupakan taraf perlakuan yang terbaik dibanding taraf perlakuan lainnya pada saat percobaan. Banyaknya kandungan bakteri bermanfaat diduga mampu meningkatkan unsur hara salah satunya nitrogen yang dibutuhkan tanaman. Nitrogen merupakan unsur hara utama dalam pertumbuhan vegetatif tanaman dan menunjang proses fotosintesis. Oleh karena itu taraf perlakuan dengan kandungan pupuk hayati $\mathrm{h}_{3}$ menjadi berbeda nyata dibanding taraf perlakuan yang lainnya dalam meningkatkan luas daun.

\section{Bobot Segar per Tanaman (g)}


Berdasarkan hasil analisis statistik dengan taraf 5\%, menunjukkan bahwa tidak terjadi interaksi antara dosis biochar dan konsentrasi pupuk hayati, namun secara mandiri dosis biochar dan konsentrasi pupuk mampu memberikan pengaruh yang berbeda nyata terhadap rata-rata bobot segar per tanaman. Nilai rata-rata luas daun dapat dilihat pada Tabel 4.

Tabel 4. Rata-rata Bobot Segar per Tanaman (g)

\begin{tabular}{lc}
\hline Perlakuan & Bobot Segar $(\mathrm{g})$ \\
\hline Dosis Biochar (B) & \\
$\mathrm{b}_{1}(0$ ton/ha) & $69,50 \mathrm{a}$ \\
$\mathrm{b}_{2}(3$ ton/ha) & $78,38 \mathrm{a}$ \\
$\mathrm{b}_{3}(6 \mathrm{ton} / \mathrm{ha})$ & $89,00 \mathrm{~b}$ \\
$\mathrm{~b}_{4}(9$ ton/ha) & $90,75 \mathrm{~b}$ \\
\hline Konsentrasi Pupuk Hayati $(\mathrm{H})$ & $76,38 \mathrm{a}$ \\
$\mathrm{h}_{0}(0 \mathrm{ml} / \mathrm{l}$ air) & $77,00 \mathrm{a}$ \\
$\mathrm{h}_{1}(5 \mathrm{ml} / \mathrm{l}$ air $)$ & $83,13 \mathrm{ab}$ \\
$\mathrm{h}_{2}(10 \mathrm{ml} / \mathrm{l}$ air $)$ & $91,13 \mathrm{~b}$ \\
$\mathrm{~h}_{3}(15 \mathrm{ml} / \mathrm{l}$ air) & Angka rata-rata yang ditandai dengan huruf yang sama \\
\hline Keterangan : & menunjukkan tidak berbeda nyata menurut Uji Lanjut Duncan \\
& pada taraf 5\%.
\end{tabular}

Hasil analisis ragam biochar menunjukkan taraf perlakuan $b_{3}$ dan $b_{4}$ dapat meningkatkan bobot segar tanaman pakcoy (Tabel 4). Hal ini sejalan dengan hasil analisis ragam tinggi tanaman, jumlah daun, dan luas daun. Pemberian biochar diduga mampu meningkatkan hasil serapan hara akibat dari kemampuan menahan air yang baik dari biochar. Biochar memiliki kandungan unsur hara dan kemampuan menahan air dan hara pada tanah. Menurut Zulfita dkk., (2019) biochar dapat berperan sebagai pembenah tanah yang memacu pertumbuhan tanaman dengan mensuplai hara dan yang lebih penting menahan hara, di samping berbagai peran lainnya yang dapat memperbaiki sifat fisik, kimia dan biologi tanah. Adanya kemampuan menahan hara yang baik dari biochar membuat efesiensi pemupukan menjadi lebih baik, oleh karena itu, yang akhirnya berdampak pada peningkatan bobot segar pakcoy dilahan percobaan.

Hasil analisis ragam pupuk hayati menunjukkan berbeda nyata antara taraf perlakuan $\mathrm{h}_{0}, \mathrm{~h}_{1}, \mathrm{~h}_{2}$ dibanding taraf perlakuan $\mathrm{h}_{3}$ (Tabel 4). Peningkatan bobot segar tajuk tanaman sawi diduga akibat dari aktivitas mikroorganisme. Hasil penelitian (Wachjar, 2006) pemberian pupuk hayati berpengaruh nyata terhadap peubah-peubah pertumbuhan tanaman teh yang belum menghasilkan. Menurut (Kalay dkk., 2016), mikroorganisme 
pada pupuk hayati pemfiksasi $\mathrm{N}$, menyediakan $\mathrm{NH}_{3}$ yang selanjutnya ditransformasi menjadi $\mathrm{NH}_{4}{ }^{+}$dan $\mathrm{NO}_{3}{ }^{-}$untuk diserap tanaman. Penambahan unsur hara dari aktivitas mikroorganisme diduga yang membuat perlakuan $\mathrm{h}_{3}$ menjadi berbeda nyata dibanding taraf perlakuan lainnya.

\section{Bobot Kering per Tanaman (g)}

Berdasarkan hasil analisis statistik dengan taraf 5\%, menunjukkan bahwa tidak terjadi interaksi antara dosis biochar dan konsentrasi pupuk hayati, namun secara mandiri dosis biochar dan konsentrasi pupuk hayati memberikan pengaruh yang berbeda nyata terhadap rata-rata bobot kering per tanaman. Nilai rata-rata luas daun dapat dilihat pada Tabel 5.

Hasil analisis ragam biochar menunjukkan berbeda nyata antara taraf perlakuan $b_{1}$ dan $b_{2}$, dibanding dengan taraf perlakuan $b_{3}$ dan $b_{4}$. Hal ini sejalan dengan hasil analisis ragam tinggi tanaman, jumlah daun, luas daun, bobot segar pertanaman.

Tabel 5. Rata-rata Bobot Kering per Tanaman (g)

\begin{tabular}{lc}
\hline Perlakuan & Bobot Kering (g) \\
\hline Dosis Biochar (B) & $2,34 \mathrm{a}$ \\
$\mathrm{b}_{1}(0$ ton/ha) & $2,84 \mathrm{ab}$ \\
$\mathrm{b}_{2}(3 \mathrm{ton} / \mathrm{ha})$ & $3,28 \mathrm{~b}$ \\
$\mathrm{~b}_{3}(6 \mathrm{ton} / \mathrm{ha})$ & $3,28 \mathrm{~b}$ \\
$\mathrm{~b}_{4}(9$ ton/ha) & $2,68 \mathrm{a}$ \\
\hline $\mathrm{Konsentrasi}$ Pupuk Hayati $(\mathrm{H})$ & $2,86 \mathrm{a}$ \\
$\mathrm{h}_{0}(0 \mathrm{ml} / \mathrm{l}$ air $)$ & $2,80 \mathrm{a}$ \\
$\mathrm{h}_{1}(5 \mathrm{ml} / \mathrm{l}$ air $)$ & $3,39 \mathrm{~b}$ \\
$\mathrm{~h}_{2}(10 \mathrm{ml} / \mathrm{l}$ air $)$ & \\
$\mathrm{h}_{3}(15 \mathrm{ml} / \mathrm{l}$ air) & Angka rata-rata pada setiap kolom yang ditandai dengan huruf \\
\hline Keterangan : & yang sama menunjukkan tidak berbeda nyata menurut Uji Lanjut \\
& Duncan pada taraf 5\%.
\end{tabular}

Bobot kering yang lebih tinggi merupakan hasil akumulasi karbon yang mampu diserap oleh tanaman sebagai akibat dari fotosintesis. Fotosintesis berkaitan erat dengan luas daun yang mampu menangkap sinar matahari dan menyerap $\mathrm{CO}_{2}$. Pengaruh luas daun yang lebih luas menyebabkan tanaman mampu melakukan fotosintesis lebih tinggi dibanding taraf perlakuan yang memiliki luas daun lebih rendah. Menurut Gardner $d k k$ (1991) Faktor utama yang mempengaruhi bobot kering total adalah radiasi matahari yang diabsorbsi dan efisiensi pemanfaatan energi tersebut untuk fiksasi $\mathrm{CO}_{2}$. Oleh karena itu 
taraf perlakuan $b_{3}$ dan $b_{4}$ yang memiliki luas daun lebih tinggi menghasilkan rata-rata bobot kering yang berbeda nyata dibanding taraf perkauan $\mathrm{b}_{1}$ dan $\mathrm{b}_{2}$ (Tabel 5).

Hasil analisis ragam pupuk hayati menunjukkan berbeda nyata antara taraf perlakuan $h_{0}, h_{1}, h_{2}$ dibanding taraf perlakuan $h_{3}$ (Tabel 5). Diduga taraf perlakuan $h_{3}$ merupakan taraf perlakuan yang terbaik dibanding taraf perlakuan lainnya pada saat percobaan. Menurut Simanungkalit (2006), pupuk hayati merupakan inokulan berbahan aktif organisme hidup yang berfungsi untuk menambat hara tertentu dalam tanah bagi tanaman. Berat kering mencerminkan akumulasi senyawa organik yang disintesis tanaman dari senyawa anorganik. Unsur hara yang diserap tanaman dari lingkungan memberi kontribusi pada berat kering tanaman (Sitompul dan Guritno, 1995).

Pupuk berbasis mikroba digolongkan ke dalam pupuk hayati karena merupakan suatu inokulan berbahan aktif organisme hidup yang berfungsi untuk menambat hara tertentu dalam tanah bagi tanaman, pupuk hayati merupakan mikroba yang diberikan kedalam tanah yang berfungsi meningkatkan pengambilan hara oleh tanaman dari dalam tanah atau udara. Penambatan unsur hara oleh bakteri membantu tanaman memperoleh unsur hara tambahan sehingga fotosintesis menjadi lebih tinggi dan menghasilkan bobot kering yang berbeda nyata.

\section{Bobot Tanaman per Plot (g)}

Berdasarkan hasil analisis statistik dengan taraf 5\%, menunjukkan bahwa tidak terjadi interaksi antara dosis biochar dan konsentrasi pupuk hayati, secara mandiri dosis biochar dan konsentrasi pupuk hayati mampu memberikan pengaruh yang berbeda nyata terhadap rata-rata bobot tanaman per plot. Nilai rata-rata luas daun dapat dilihat pada Tabel 6.

Hasil analisis ragam biochar menunjukkan taraf faktor $\mathrm{b}_{4}$ dapat meningkatkan bobot tanaman per plot (Tabel 6). Hal ini sejalan dengan hasil analisis ragam tinggi tanaman, jumlah daun, luas daun, bobot segar pertanaman, dan bobot kering per tanaman.

Tabel 6. Rata-rata Bobot Tanaman per Plot (g)

\begin{tabular}{lc}
\hline Perlakuan & Bobot per Plot $(\mathrm{g})$ \\
\hline Dosis Biochar $(\mathrm{B})$ & \\
$\mathrm{b}_{1}(0$ ton/ha) & $792,50 \mathrm{a}$ \\
$\mathrm{b}_{2}(3$ ton/ha) & $834,38 \mathrm{a}$ \\
$\mathrm{b}_{3}(6$ ton/ha) & $906,25 \mathrm{~b}$ \\
$\mathrm{~b}_{4}(9$ ton/ha) & $971,88 \mathrm{c}$ \\
\hline Konsentrasi Pupuk Hayati $(\mathrm{H})$ & \\
$\mathrm{h}_{0}(0 \mathrm{ml} / \mathrm{l}$ air $)$ & $826,88 \mathrm{a}$ \\
\hline
\end{tabular}




\begin{tabular}{lc}
\hline $\mathrm{h}_{1}(5 \mathrm{ml} / \mathrm{l}$ air $)$ & $868,75 \mathrm{a}$ \\
$\mathrm{h}_{2}(10 \mathrm{ml} / \mathrm{l}$ air $)$ & $875,00 \mathrm{a}$ \\
$\mathrm{h}_{3}(15 \mathrm{ml} / \mathrm{l}$ air $)$ & $934,38 \mathrm{~b}$ \\
\hline Keterangan : & Angka rata-rata pada setiap kolom yang ditandai dengan huruf \\
& yang sama menunjukkan tidak berbeda nyata menurut Uji Lanjut \\
& Duncan pada taraf 5\%.
\end{tabular}

Biochar secara umum mempunyai fungsi lebih persisten dalam tanah, sehingga semua manfaat yang berhubungan dengan retensi hara dan kesuburan tanah dapat berjalan lebih lama dibandingkan tanpa pemberian biochar. Aplikasi biochar secara nyata berpotensi dalam meningkatkan beberapa sifat kimia tanah seperti $\mathrm{pH}$ tanah, KTK, dan beberapa senyawa seperti C-organik, $\mathrm{N}$-total, serta dapat mereduksi aktivitas senyawa $\mathrm{Fe}$ dan $\mathrm{Al}$ yang berdampak terhadap peningkatan $\mathrm{P}$ tersedia. Hal ini sesuai dengan penelitian Rondon dkk., (2007) yang menyatakan bahwa penggunaan biochar dapat meningkatkan fiksasi nitrogen, memperbaiki pertumbuhan dan meningkatkan hasil tanaman.

Hasil analisis ragam pupuk hayati menunjukkan berbeda nyata antara taraf perlakuan $h_{0}, h_{1}, h_{2}$ dibanding taraf perlakuan $h_{3}$ (Tabel 6). Diduga taraf perlakuan $h_{3}$ merupakan taraf perlakuan yang terbaik dibanding taraf perlakuan lainnya pada saat percobaan. Peningkatan pertumbuhan pakcoy yang diberi perlakuan pupuk hayati bukan hanya akibat dari meningkatnya unsur hara pun adanya hormon yang dihasilkan dari mikroba yang terkandung dalam pupuk hayati. Kemampuan mikroba dalam menghasilkan zat tumbuh alami dan mensintesis asam indol asetat aeperti Azospirillum berperan dalam meningkatkan hasil panen pada berbagai jenis tanah maupun iklim yang berbeda dan menurunkan kebutuhan pupuk nitrogen sampai 35\% (Fallik dan Okon, 2006).

Hormon yang dihasilkan tegantung dari bakteri pada pupuk. Pada kemasan Bion Up (pupuk yang digunakan penulis) yang diaplikasi dilapangan mengandung bakteri dan jamur menguntungkan seperti Azotobacter chococcum, A. vinelandi, Azospirilum sp, Pseudomonas cepacia, Penicillium sp, Acinetobacter sp dengan populasi masing-masing e" $107 \mathrm{CFU} / \mathrm{mL}$. Azotobacter dikenal sebagai rizobacter penambat $\mathrm{N}_{2}$ di perakaran tanaman, dapat memproduksi fitohormon diantaranya sitokinin dan giberalin (Hindersah dkk., 2018). Azospirillum dikenal juga sebagai bakteri penambat nitrogen $\left(\mathrm{N}_{2}\right)$ mencapai $40-80 \%$ (Eckert $d k k, 2001$ ) dan menghasilkan fitohormon IAA (Oedjijono $d k k, 2012$ ), yang berperan dalam peningkatan pertumbuhan dan hasil tanaman. Acinetobacter dikenal 
sebagai bakteri pemicu pertumbuhan tanaman (Plant Growth Promoting Bacterium) yang dapat meningkatkan kandungan klorofil pada tanaman monokotil dan dikotil dalam sistem budidaya tanaman (Suzuki $d k k, 2014)$. Oleh karena itu Pengaruh dari berbagai mikroorganisme tersebut yang mampu menambahkan tambahan unsur hara dan hormon tumbuh menjadikan taraf perlakuan berbeda nyata antara $b_{1}, b_{2}$ dibandingkan taraf $b_{3}$ dan $\mathrm{b}_{4}$.

\section{Kesimpulan}

Berdasarkan hasil penelitian dapat ditarik kesimpulan sebagai berikut:

1. Tidak terdapat interaksi antara biochar dan pupuk hayati terhadap pertumbuhan dan hasil tanaman pakcoy (Brassica rapa L.).

2. Secara mandiri, pemberian dosis biochar 6 dan 9 ton/ha dan pemberian pupuk hayati $15 \mathrm{ml} / \mathrm{l}$ memberikan pengaruh yang berbeda nyata terhadap pertumbuhan dan hasil tanaman pakcoy (Brassica rapa L.).

\section{DAFTAR PUSTAKA}

Alianti Y, S. Zubaidah, \& D. Saraswati. 2016. Tanggapan Tanaman Tomat (Lycopersicum esculentum Mill.) terhadap Pemberian Biochar dan Pupuk Hayati pada Tanah Gambut. Skripsi. Jurusan Budidaya Pertanian, Fakultas Pertanian, Universitas Palangka Raya. Kalimatan Tengah.

Anggraheni W., N. Aini \& S. Heddy. 2017. Pengaruh Konsentrasi dan Frekuensi Pemberian Pupuk Hayati terhadap Pertumbuhan dan Hasil Cabai Besar (Capsicum annum L.). Jurnal Produksi Tanaman Vol. 5 No. 1 : 84 - 91.

Antonius, S \& D. Agustiyani. 2011. Pengaruh Pupuk Organik Hayati yang Mengandung Mikroba Bermanfaat terhadap Pertumbuhan dan Hasil Panen Tanaman Semangka Serta Sifat Biokimia Tanah pada Percobaan Lapang di Malinau Kaltim. Jurnal Berkala Penelitian Hayati. 16(1) 203-6.

Coenye, T \& P. Vandamme. 2003. Minireview: Diversity and Significance of Burkholderia Species Occupying Diverse Ecological Niches. Environmental Microbiology 5(9), 719-729.

Eckert, B., O.B. Weber, G. Kirchhof, A. Halbritter, M. Stoffels, \& A. Hartmann. 2001. Azospirillum Doebereinerae sp. nov., A Nitrogen-Fixing Bacterium Associated with the C4-grass Miscanthus. International J. of Systematic and Evolutionary Microbiology. 51:17-26.

Fallik, E. \& Y. Okon. 2006. The Responses of Maize (Zea mays) to Azospirillum Inoculation in Various Types of Soils in the Field. World J. Biotechnology. 1 (2): 511-515.

Gardner F.P., R.B. Pearce, \& R.L. Mitchell. 1991. Physiology of Crop Plants. Diterjemahkan oleh H. Susilo. Jakarta. Universitas Indonesia Press. 
Hale, S.E., V. Alling, V. Martinsen, J. Mulder, G.D. Breedveld, \& G. Cornelissen. 2013. The Sorption and Desorption of Phosphate-P, Ammonium-N and Nitrate $\mathrm{N}$ in Cacao Shell and Corn Cob Biochars. Chemosphere. 91: 1612-1619.

Haryanto, E, T. Suhartini, E. Rahayu \& H. H. Sunarjono. 2007. Sawi dan Selada. Penebar Swadaya. Jakarta.

Hindersah, R., M. Kalay, A. Talahaturuson, \& Y. Lakburlawal. 2018. Nitrogen Fixing Bacteria Azotobacter As Biofertilizer and Biocontrol in Long Bean. Agric. 30(1), 25-32.

Juhari, Sulakhudin, \& U. E. Suryadi. 2021. Pengaruh Perlakuan Pupuk Kandang Sapi dan Biochar terhadap Ketersediaan Hara Makro dan Pertumbuhan Tanaman Jagung Manis pada Tanah Pasca Peti. Artikel Ilmiah Jurusan Ilmu Tanah Universitas Tanjungpura Fakultas Pertanian. 47320-75676642684-1-PB.pdf

Kalay, A. M., M.R. Uluputty, J. M. A. Leklioy, \& R. Hindersah. 2016. Aplikasi Pupuk Hayati Konsorsium Dan Inokulan Padat Trichoderma harzianum Terhadap Produktivitas Tanaman Sawi Pada Lahan Terkontaminasi Rhizoctonia solani Application of Trichoderma harzianum Solid Inokulan And Biofertilizer Consortium on Choy Sum Product. Agrologia. 5(2), 78-86.

Ketut, I. S., P. Sujana, \& Made, I. S. 2017. Pengaruh Pemberian Biochar terhadap Tanaman Sawi Hijau (Brassica juncea L.) pada Lahan yang Tercemar Limbah Cair di Subak Cuculan Desa Kepaon. Agroteknologi, Fakultas Pertanian, Universitas Mahasaraswati Denpasar.

Kumar M.M., Khisore, G.G., M. Ram, B. Ranu, \& M. Kapur. 2017. Pyrolysis of Chemicall Treated Corncob for Biochar Production and Its Aplication in C. r(VI) Removal. Enveromental Progress and Sustainable Energy.

Kurniadi, A. 1996. Sayuran yang Digemari. Harian Suara Tani. Jakarta.

Lehmann J. \& S. Joseph. 2009. Biochar for Environmental Management: An Introduction. Science and Technology (Johannes Lehmann and Stephen Joseph Eds.). First published by Earthscan in the UK and USA in 2009.

Nafi'ah, H. H., R. Hindersah, S. Mubarok, H. Maulana, T. Suganda, V. Concibido, \& A. Karuniawan. 2021. Growth rate and yield response of several sweet potato clones to reduced inorganic fertilizer and biofertilizer. Biodiversitas, 22(4), 1775-1752.

Nafi'ah, H. H., A. Y. Rismayanti, \& A. Karuniawan. 2019. Hasil Tiga Klon Ubi Kayu (Manihot esculenta Crantz.) terhadap Perbedaan Dosis Pupuk Hayati. Jurnal Agro Wiralodra, 2(2), 67-72.

Oedjijono U.W., E.K. Lestanto, Nasution, \& Bondansari. 2012. Pengaruh Azospirillum spp. terhadap Pertumbuhan Tanaman Jagung (Zea mays L.) dan Kemampuan Beberapa Isolat dalam Menghasilkan IAA. Dalam Prosiding Seminar Nasional. 156-163.

Pakpahan, T.E., T. Hidayatullah, \& E. Mardiana. 2020. Aplikasi Biochar dan Pupuk Kandang Terhadap Budidaya Bawang Merah di Tanah Inceptisol Kebun Percobaan Politeknik Pembangunan Pertanian Medan. Jurnal Agrica Ekstensia. 14 (1): 49-53.

Pracaya dan J. K. Kartika. 2016. Bertanam 8 Sayuran Organik. Penebar Swadaya. Jakarta.

Prasetyo, A. 2010. Kubis Tiongkok Alias Pakcoy. http:koebiz.blogspot.com/ 2010/10/kubis-tiongkok-alias-pakcoy.html. Diakses pada tanggal 16 Maret 2021.

Rondon M, J. Lehmann, J. Ramirez, \& M. Hurtado. 2007. Biological Nitrogen Fixation by Common Beans (Phaseolus vulgaris L.) Increases with Bio-char Additions. Biol Fert Soils. 43:699-708. 
Sasmita, A., A. Syakinah, \& U. Nisa. 2021. Pengaruh Penambahan Biochar Terhadap Penurunan Kadar Total Petroleum Hydrocarbon (TPH) Pada Tanah Tercemar Minyak Bumi. Jurnal Tanah dan Sumberdaya Lahan. 8 (2): 407-414.

Septiana, L.M., H. Indhira, Afandi, \& I.S. Banuwa. 2021. Efektivitas Bahan Pembenah Tanah Terhadap Distribusi Agregat di Lahan Kering Masam pada Pertanaman Kedelai. Jurnal Agrotektropika. 9 (2): 251-259.

Setiawati, M.R., P. Suryatmana, R. Hindersah, B.N. Fitriatin, \& D. Herdiyantoro. 2014. Karakterisasi Isolat Bakteri Pelarut Fosfat untuk Meningkatkan Ketersedian P pada Media Kultur Cair Tanaman Jagung (Zea mays L.). Bionatura - Jurnal IlmuIlmu Hayati dan Fisik. 16(1), 30-34.

Simanungkalit, R. D. M., Suriadikarta, D.A., Saraswati, R., Setyorini, D \& W. Hartatrik. 2006. Pupuk Organik dan Pupuk Hayati. Balai Besar Litbang Sumberdaya Lahan Pertanian, Badan Penelitian dan Pengembangan Pertanian.

Sitompul, S. M. \& B. Guritno. 1995. Analisis Pertumbuhan Tanaman. Yogjakarta. UGM Press.

Surianti, K., Syakur., \& Darussman. 2021. Efektivitas Biochar Sekam dan Jerami Padi Pada Tanah Bekas Tambang Batubara Terhadap Sifat Kimia Tanah pada Tanaman Jagung Manis. Jurnal Ilmiah Mahasiswa Pertanian. 6 (2): 105-111.

Suzuki, W., M. Sugawara, K. Miwa, \& M. Morikawa. 2014. Plant Growthpromoting Bacterium Acinetobacter Calcoaceticus P23 Increases the Chlorophyll Content of the Monocot Lemna Minor (Duckweed) and the Dicot Lactuca sativa (Lettuce). $J$ Biosci Bioeng. 118 (1): 41-44.

Wachjar, A. 2006. Pengaruh Beberapa Jenis Pupuk Hayati terhadap Pertumbuhan Dua Klon Tanaman Teh (Camellia sinensis (L) O. Kuntze) Belum Menghasilkan. Jurnal Agronomi Indonesia (Indonesian Journal of Agronomy). 34(3), 160-164.

Winata, P. \& A.B. Zainul. 2020. Pengaruh Pemberian Biochar Batang Tembakau dan Mikoriza Terhadap Produktivitas Tembakau (Nicotiana tabaccum) Besuki NAOOGST. Berkala Ilmiah PERTANIAN. 3 (1): 7-15.

Yuliani. 2015. Pemanfaatan Mol (Mikroorganisme Lokal) Keong Emas (Pomoceae canaliculata) dan Pupuk Organik untuk Peningkatan Pertumbuhan dan Hasil Tanaman Sawi (Brassica rapa L.). Jurnal Agroscience. 5(2): 7-12.

Zulfita, D., Surachman \& E. Santoso. 2019. Aplikasi Biochar Sekam Padi Dan Pupuk NPK Terhadap Serapan N, P, K Dan Komponen Hasil Jagung Manis Di Lahan Gambut. Program Studi Agroteknologi, Fakultas Pertanian, Universitas Tanjungpura Pontianak. 